\title{
PANCREATICOPLEURAL FISTULA
}

\author{
Fístula pancreaticopleural \\ Ricardo Duarte MOTA, Camila Oliveira ALCÂNTARA, \\ Leandro Moreira ANTUNES, Antônio Sérgio Barcala JORGE
}

From State University of Montes Claros, Clemente Faria Hospital, Montes Claros, MG Brazil.

\section{Correspondence: Montes Claros, MG, CEP: 39401002, Brasil \\ Financial source: none \\ Conflicts of interest: none \\ Recived for publication: 17/05/2010}

Antônio Sérgio Barcala Jorge - Hospital Universitário Clemente Faria (Clínica Cirúrgica), Avenida Cula Mangabeira, n 562, Santo Expedito,

Accepted for publication: 07/02/2011

\section{INTRODUCTION}

$\mathrm{P}$ ancreaticopleural fistula is $\operatorname{rare}^{3,4,5,8}$. Was first described in 1973 by Tombroff ${ }^{10}$. Is estimated to occur in $0.4 \%$ of patients with pancreatitis. It is related, in $99 \%$ of cases, as due to alcoholic cause ${ }^{5,11,14}$. It may occur through two mechanisms: directly via the main pancreatic duct with the pleural cavity or, more often, through a pseudocyst ${ }^{7,8,9,15}$. Produces massive and recurrent pleural effusions, usually on the left side associated to high content of amylase $e^{8,11}$, with concomitant identification to high serum levels of this enzyme ${ }^{15}$. The chest radiograph shows pleural effusion ${ }^{7,8}$. and ultrasound imaging of abdomen and thoracoabdominal computed tomography can visualize the pancreas with its changes and possible pseudocyst ${ }^{6,7,8}$. Fistula can be also diagnosed by endoscopic retrograde cholangiopancreatography ${ }^{7,14}$ or magnetic resonance cholangiopancreatography ${ }^{14,15}$ and with less sensitivity by computed tomography4,14. Conservative treatment consists of total parenteral nutrition, somatostatin, thoracentesis or chest tube drainage in water seal ${ }^{17,7,8,11,14,15}$. Endoscopic treatment consists of placing implants inside Wirsung's duct and sphincterotomy $y^{1,4,7,14,15}$. Surgical treatment consists of drainage with the preparation of pancreatic anastomosis with an intestinal segment ${ }^{14}$ and / or distal pancreatectomy alone $\mathrm{e}^{1,2,14,15}$.

\section{CASE REPORT}

Woman of 52 years smoker and heavy alcoholic drinker looked for medical assistance on emergency department for dyspnea since a month ago, with sharp increase in the last two weeks. She also reported appetite loss, weight loss, dependent chest pain and fever. She denied abdominal complaints. Physical examination verified very thin prson, pale mucous membranes $(2+/ 4+)$, febrile and with mild tachypnea. In lung auscultation was observed vesicular murmur in the lower two-thirds of the right hemithorax and left lower third, with dullness to percussion. The abdomen was flat with no palpable masses or visceromegaly and painless on palpation.

The laboratory tests showed normocytic and normochromic anemia, liver and renal profile unchanged. Chest radiography showed bilateral pleural effusion, most importantly the right. Was performed pleural biopsy and thoracentesis. The analysis revealed cloudy pleural fluid, $\mathrm{pH}=8$, density 1015, with a predominance of polymorphonuclear cytology, bacteriology negative, absence of fungi and negative for malignancy. Relationship was identified pleural protein / serum protein of 0.55 , compared pleural LDH / serum LDH 7.0 and pleural LDH of 1463, as well as ADA and 6-amylase over 2000. Pleural biopsy showed nonspecific pleuritis. Chest tube placed to water seal. The patient developed fever. Was also performed screening for gynecological cancer, lung and metastatic esophageal fistula, all with negative results. Abdominal CT scan suggested chronic pancreatitis with pancreatic pseudocysts. The serum amylase was 2015.

The patient underwent total parenteral nutrition for two weeks, but remained with active fistula. Was decided to do a derivation with pancreatojejunal longitudinal anastomosis Roux-en- $Y$ style with splenic preservation (Partington and Rochelle procedure). The operation was uneventful. The patient was discharged after the 9th postoperative day, under favorable conditions. 


\section{DISCUSSION}

Ali et al. ${ }^{1}$, in a recent review of 52 published cases and Uchiyama et al. ${ }^{11}$ in a review of 113 cases in Japan reported dyspnea, abdominal pain, cough and chest pain as the main symptoms in patients with fistula. Pleural effusions with high-amylase can also be found in acute pancreatitis, gynecological cancer, lung, metastatic tumors, pneumonia, esophageal perforation, lymphoma, leukemia and pulmonary tuberculosis ${ }^{4}$.

Abdominal CT, despite its low sensitivity, was initially applied in order to reveal features of chronic pancreatitis, and pancreatic calcification and pseudocysts ${ }^{1}$. However, some authors argue that ERCP should be performed initially ${ }^{15}$. Some series show ${ }^{1}$ confirmation of the diagnosis in $78 \%$ of cases with its use. Should be taken into account, however, the fact of not being able to demonstrate fistulas in locations where the breakpoint is in distal duct, the CT scan should be the method of choice in these cases $^{11}$. Magnetic resonance cholangiopancreatography was effective for the diagnosis of fistula in several studies ${ }^{1,12,13}$. It is non-invasive method, without contrast and free of infectious risks ${ }^{1,12,13}$. The abdominal ultrasound is not considered effective for diagnosis due to its low sensitivity, since the gaseous intestinal distension and the presence of air in the stomach affect the identification of fistulas ${ }^{1,4,7,11,13}$.

There are no guidelines for the treatment of fistula based on randomized clinical trials. The management is grounded in case reports and case series ${ }^{1,11}$. Initially, the clinical treatment is carried out for two to three weeks consisting of total parenteral nutrition, somatostatin analogues associated with chest tube drainage and water-sealed ${ }^{1,7,11,13}$. It should be remembered that the reduction in pancreatic secretion is less important than the restoration of anatomic continuity of the pancreatic duct ${ }^{1,9}$. The effectiveness of conservative treatment ranges from 30 to $60 \%$ in some series ${ }^{1}$ and $0 \%$ to $33 \%$ in others ${ }^{4}$. Recently, endoscopic treatment has gained ground that consists of balloon dilatation and prosthesis intraductal ${ }^{1,4,7,11,13}$. The stent may allow for drainage of pancreatic secretion into the duodenum and has reported success rates up to $25 \%$ with endoscopic treatment.

The failure of conservative treatment indicates surgical treatment. The type of procedure is determined in accordance with the portion ${ }^{12}$ and pancreatic affected by the anatomy of the pancreatic duct. Complete rupture of the pancreatic duct and the presence of large volume pseudocysts are clear indications for surgical treatment ${ }^{1}$. A distal pancreatectomy is part of the procedure with the highest number of reports in the literature ${ }^{1,11}$. In patients with pseudocysts, it is necessary to perform internal drainage with pancreatojejunostomy ${ }^{1,9,11}$.

\section{CONCLUSION}

Pancreaticopleural fistula is rare condition that should be suspected especially in patients with a history of pancreatitis or alcoholism abuse with respiratory symptoms or pleural effusion.

\section{REFERENCES}

1. Ali $T$, Srinivasan $N$, Vu Le, Chimpiri $R$, Tierney $M$. Pancreaticopleural Fistula. Pâncreas 2009; 38 (1): 26- 31.

2. Bishop J, McClean P, Davison S, Sheridan M, Zamvar $V$, Humphrey G, Stringer M. Pnacreaticopleural Fistula: A Rare Cause of Massive Pleural Effusion. J Ped Gastroenterology and Nutrition 2003; 36: 134- 137.

3. Burgess NA, Moore HE, Williams JO, Lewis MH. A review of pancreaticopleural fistula in pancreatitis and its management. HPB Surg 1992; 5: 79- 86.

4. Dhebri AR, Ferran N. Nonsurgical Management of Pancreaticopleural Fistula. J Pancreas 2005; 6 (2): 152-161.

5. Hastier P, Rouquier P, Buckley m, Simler JM, Dumas R, Delmont JP. Endoscopic treatment of Wirsungo- cysto- pleural fistula. Eur J Gastroenterol Hepatol 1998; 10: 527-9.

6. Monteiro E, Terra JCA, Figueiredo LBP, Miranda LHS. Pseudocisto de pâncreas associado a derrame pleural maciço. J Pneumol 28 (3): 159-162.

7. Ribeiro B, Gomes D, Rosa A, Amaro P, Tomé L, Leitão M, Freitas D. Derrame pleural recidivante por fístula pancreático-pleural. Jornal Português de Gastroenterologia 2000; 7: 161-164.

8. Rockey DC,Cello JP. Pancreaticopleural fistula. Report of 7 pacients and review of literature. Medicine (Baltimore). 1990; 69: 332-344.

9. Shibasaki S, Yamaguchi H, Nanashima A, Tsuji T, Jibiki M, Sawai T, Yasutake T, Nakagoe T, Ayabe H. Surgical Treatment for Right Pleural Effusions caused by Pancreaticopleural Fistula. Hepato-Gastroenterology 2003; 50: 1678-1680.

10.Trombroff M, Loiq A, Koster JP, Engleholm L, Govaerts JP. Pleural effusion with pancreaticopleural fistula. British Medical Journal 1973; 1 330-331.

11.Uchiyama T, Suzuki T, Adachi A, Hiraki S, Iizuca N. Pancreatic Pleural Effusion: Case Report and Review of 113 Cases in Japan. American Journal of Gastroenterology 1992; 87, (3): 387-391.

12. Vyas S, Gogoi D, Sinha SK, Singh P, Yadav TD. Khandelwal N. Pancreaticopleural Fistula: An Unusual Complication of Pancreatitis Diagnosed with Magnetic Resonance Cholangiopancreatography. J Pancreas 2009; 10 (6): 671-673.

13. Wakefield S, Tutty B, Britton J.Pancreaticopleural fistula: a rare complication of chronic pancreatitis. Postgrad Med J 1986; 72 (844):115-116

14. Young S, Steven A, Edmundowicz, Sreenivasa S, Jonnalagadda, Riad R. Pancreaticopleural Fistula: Report of Two Cases and Review of the Literature. Digestive Deseases and Scienses 2006; 51,(1): 1-6.

15.Zubiaurre L, Oyarzabal I, Berguiristain A, Amato E, Zapata E, Salvador P. Fistula pancreaticopleural: pruebas diagnósticas y tratamiento. Cir Esp. 2005; 77 (6): 359- 61. 